\title{
Sounds and Pronunciation (Children's First Language Acquisition Model in the Pragmatic Process)
}

\author{
Memmy Dwi Jayanti*) \\ Universitas Indraprasta PGRI \\ *) Jalan Nangka Raya No.58 C, RT.5/RW.5, Tj. Barat., Kec. Jagakarsa, Jakarta Selatan, Indonesia; \\ e-mail: memmydj@gmail.com
}

\begin{abstract}
The aim of the study was to determine the stages of the linguistic first language acquisition process which emphasized the aspects of sound and pronunciation in children aged two to four years. Research focuses on phonological analysis of sound and pronunciation in a pragmatic perspective. This type of qualitative research uses a cross sectional approach, namely data collection from the age of two to four years at the same time in order to obtain complete and fast data so that it can describe each individual in the process of acquiring his language. The focus of research is all sounds or sounds that are spoken or produced by the child in a pragmatic view, namely when communicating. Sub focus in research is the sound and pronunciation of children according to the theory of Susan M. Gass and Larry Se, at the initial stage the pronunciation of children is not the same as the pronunciation of adults. Some sounds can be distinguished at first such as: the difference between consonants in [ta] and [da]. Even when children start using words that more or less resemble adult words, at least in a sense, there are different pronunciations, namely deletion of syllables (em..bek $\rightarrow$ goat), elimination of sound (japah $\rightarrow$ jerapah $\rightarrow$ giraffe), and simplification process words (fis $\rightarrow$ fish). The results showed that there was a relationship between the ability of sound produced by children and pragmatic rules according to their age. In the acquisition of languages and stages of linguistic processes with almost the same age there are also differences between children with each other.
\end{abstract}

Keywords: First Language Acquisition, Linguistic Knowledge, Sounds and Pronuncitation.

Article History: Received: 20/05/2019; Revised: 23/06/2019; Accepted: 05/07/2019; Published: 31/07/2019. How to Cite

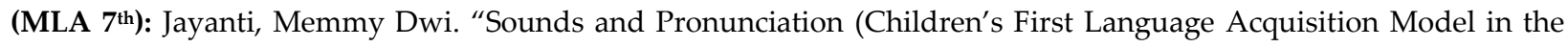
Pragmatic Process)." Hortatori Jurnal Pendidikan Bahasa dan Sastra Indonesia 3.01 (2019): 30-37. Print/Online. Copyrights Holder: Memmy Dwi Jayanti. First Publication: Hortatori Jurnal Pendidikan Bahasa dan Sastra Indonesia (2019).

This work is licensed under a Creative Commons Attribution-ShareAlike 4.0 International License.

\section{Pendahuluan}

Proses pemerolehan bahasa pertama pada anak secara linguistik dapat ditekankan pada aspek fonologis salah satunya yaitu suara dan pengucapan (sounds and pronunciation). Menurut (Susan M. Gass dan Larry Se, 2008) pada proses tahapan suara dan pengucapan terdapat perbedaan antara pengucapan anak dan orang dewasa. Beberapa suara dapat dibedakan di awal saja seperti: perbedaan antara konsonan dalam [ta] dan [da]. Selain itu, ketika bahasa pada anak-anak menggunakan kata-kata yang kurang lebih menyerupai kata-kata orang dewasa, sehingga baik arti juga terdapat perbedaan dalam pengucapannya. Contoh, penghapusan suku kata pada kata 'dedo' yang mengacu pada kata 'potato' yaitu 'kentang', lalu ada penghapusan suara untuk kata 'tein yang mengacu pada kata 'train' yaitu 'kereta', dan proses penyerdehanaan seperti kata 'fis' yang mengacu pada kata 'fish' yaitu 'ikan'. Pemerolehan bahasa pertama pada anak merupakan kegiatan satu atau lebih bahasa yang dapat dipelajari dalam lingkungan keluarga, pemerolehan bahasa pertama yang dimaksudkan adalah semua bahasa yang digunakan oleh anak-anak atau serangkaian bahasa yang diambil seorang anak sebelum mereka memasuki usia sekolah. Pada kajian fonologis suara dan pengucapan dalam perspektif pragmatik merupakan kemampuan bunyi yang dihasilkan oleh anak-anak dengan aturan pragmatis sesuai dengan usianya. Berdasarkan latar belakang tersebut mekanisme pemerolehan bahasa pada anak usia dini yaitu usia antara dua sampai dengan empat tahun 
meliputi proses pemerolehan bahasa pada anak dan kemampuan bahasa anak ketika berbicara. Bahasa yang diucapkan oleh anak tersebut akan dikaji dalam bentuk penelitian, karena bahasa pertama merupakan bahasa orang tua dan diikuti oleh anak. Salah satu yang akan menjadi keunikan tersendiri dalam penelitian ini adalah jika anak tersebut memiliki perbedaan dalam pemerolehan bahasa dan tahapan proses linguistik dengan usia yang hampir sama. Artinya, antara anak satu dengan lainnya akan memiliki perbedaan dalam proses bahasanya yang nantinya akan dikaitkan dengan teori sebagai suatu rujukan. (Kidd, Donnelly, \& Christiansen, 2018) dalam penelitiannya menjelaskan bahwa terdapat perbedaan ciri-ciri bahasa pada anakanak yang terdapat dalam banyak hal, melalui variasi yang dapat diamati pada tiap-tiap tingkat deskripsi sampai dengan aspek sosial. Teori linguistik dan psikolinguistik memungkinkan perbedaan bermakna dalam bahasa di antara tiap-tiap individu. Pada masa pemerolehan bahasa anak lebih mengarah pada fungsi komunikasi dari bentuk bahasanya, beberapa tahapan mulai dari tahap awal pemerolehan dalam bentuk ocehan sampai dengan mencapai puncaknya ketika anak dapat membentuk kalimat yang hampir menyerupai bahasa orang dewasa. Dalam prosesnya, bahasa pada anak akan dimulai dengan memproduksi bunyi. Artinya, bunyi paling awal yang belum mempunyai makna dan tidak beraturan. Kemudian, jika memungkinkan anak akan mulai memproduksi suku kata, frase, sampai kalimat yang berterima. Penelitian yang berjudul "Individual Differences in Language Acquisition and Processing" mengacu pada konsep penelitian yaitu mencari perbedaan ciri dari manusia dalam banyak hal, dengan variasi yang dapat diamati pada tiap tingkat deskripsi sampai aspek sosial. Secara tradisional, teori linguistik dan psikolinguistik telah kemungkinan perbedaan bermakna dalam bahasa di antara individu. Namun, menjadi semakin jelas bahwa ada variasi yang signifikan di antara penutur pada usia berapa pun dan di seluruh umur. Penelitian terbaru dalam psikolinguistik, dan berpendapat bahwa fokus pada perbedaan individu dalam memberikan sumber bukti penting yang sangat mendukung isu-isu inti dalam teori akuisisi dan pemrosesan bahasa; khususnya, peran pengalaman dalam penguasaan bahasa, pemrosesan, pencapaian, dan arsitektur sistem bahasa.

Menurut (Ingram, 1989) teori persepsi ujaran dicetuskan pertama kali oleh kaum behaviorisme, nativisme, konstruksionisme, dan maturasionisme. Umumnya kemampuan seorang anak dalam memperoleh bahasa pertama tidak secara tiba-tiba dan tidak lengkap beserta semua kaidahnya. Artinya, bahasa pertama diperoleh dalam beberapa tahapan dan tiap tahap berikutnya akan lebih mendekati tata bahasa seperti orang dewasa. Terdapat beberapa teori yang mendukung dalam pemerolehan bahasa pada anak, diantaranya: Behaviorisme yaitu kajian teori yang menyoroti aspek perilaku kebahasaan yang dapat diamati Secara langsung dan berhubungan antara rangsangan (stimulus) dan reaksi (response). Perilaku bahasa yang efektif adalah membuat reaksi yang tepat terhadap suatu rangsangan, reaksi tersebut akan menjadi suatu kebiasaan yang baik jika dibenarkan dalam penerapannya pada anak sehingga anak belajar bahasa pertamanya dengan baik dan benar. Misalnya, ketika anak mengucapkan kata 'bilangkali' untuk kata yang dimaksudkan 'barangkali', dalam kasus tersebut tentunya tidak benar, maka baik orang tua atau siapa saja yang mendengar kata tersebut agar tidak menjadi suatu kebiasaan yang tidak benar dalam pengucapannya. Kemampuan berbicara dan memahami bahasa oleh anak juga diperoleh melalui rangsangan dari lingkungannya. Nativisme yaitu suatu paham yang mempercayai bahwa tiap-tiap anak lahir sudah dibekali dengan suatu alat untuk memperoleh suatu bahasa yang disebut dengan LAD (language acquisition device). Mengenai bahasa apa yang akan diperoleh oleh anak bergantung pada bahasa apa yang digunakan atau biasa disebut dengan bahasa target/TL (Target Language), bahasa target mengacu pada bahasa apa yang dipelajari oleh anak. Misalnya, seorang anak yang dibesarkan di Amerika berbeda dengan anak yang dibesarkan di Cina, dalam hal ini terkait dengan bahasa pertamanya, sehingga dapat dikatakan tiap-tiap anak dapat belajar bahasa apa saja yang digunakan di lingkungannya. Teori nativisme dalam pemerolehan bahasa pertama dapat dikatakan bahwa selama proses pemerolehannya, anak sedikit demi sedikit membuka kemampuan lingualnya yang secara genetis telah diprogramkan. Jadi, lingkungan sama sekali tidak memiliki pengaruh dalam proses pemerolehan (acquisition), hal tersebut diperkuat oleh pernyataan Chomsky yang menyatakan bahwa bahasa dianggap terlalu kompleks untuk dipelajari dalam waktu yang dekat melalui metode tiruan (imitation) seperti anggapan kaum behaviorisme. Nurture dan Nature sama-sama saling mendukung, artinya nature diperlukan karena tampa bekal secara kodrati tidak mungkin anak dapat berbahasa, sedangkan nurture diperlukan karena tanpa input dari alam sekitar bekal yang kodrati itu tidak akan terwujud. Kognitivisme menyatakan bahwa perkembangan bahasa harus berlandaskan pada perubahan yang lebih mendasar dan lebih umum di dalam kognisi. Artinya, urutan-urutan perkembangan kognitif menentukan dalam dalam bentuk keterampilan berbahasa. Teori kognitivisme dalam perolehan bahasa pertama misalnya pada anak usia 0;18 bulan, bahasa dianggap belum ada, artinya anak hanya memahami dunia melalui panca 
indranya. Pada akhir usia satu tahun, tahap berikutnya adalah anak sudah dapat mengerti bahwa benda memiliki sifat permanen sehingga mulai menggunakan simbol untuk mempresentasikan benda yang tidak hadir dihadapannya. Simbol ini kemudian akan berkembang menjadi kata-kata awal yang diucapkan oleh anak. Dalam pemerolehan bahasa pertama memang sangat dipengaruhi oleh tiap-tiap anak, hal inilah yang menyatakan bahwa kemampuan berbahasa pada anak telah ada sejak lahir. (Thornton, 2012) dalam penelitian "Studies at the interface of child language and models of language acquisition" menjelaskan tentang beberapa asumsi umum tentang penguasaan bahasa pertama, diantaranya: bahwa anak-anak dilahirkan dengan kecenderungan bawaan untuk memperoleh suatu bahasa. Selain itu, juga memprediksikan bahwa anak-anak memiliki bahasa bawaan tertentu dengan arsitektur modular. Pada desain eksperimental, menunjukkan bahwa metodologi yang kurang optimal dapat menyebabkan kesalahan pada anak-anak (dan orang dewasa) yang kadang-kadang ditafsirkan berasal dari sumber lain, kajian sintaksis-wacana menonjol sebagai masalah dan sumber banyak perdebatan tentang transfer antarbahasa yang belum diselesaikan.

Pragmatik merupakan bagian dari perilaku berbahasa, maka pemerolehan bahasa juga perlu mengamati bagaimana anak mengembangkan kemampuan pragmatiknya. Menurut (Sarah A. Liszka, 2004) dalam penelitian "Exploring the effects of first language influence on second language pragmatic processes from a syntactic deficit perspective" berusaha mempertimbangkan fungsi gramatikal yang dapat berkontribusi pada pemrosesan pragmatis pada tingkat pembentukan explicature atau pemulihan, dengan asumsi bahwa penguraian pengetahuan tata bahasa secara logis memulai pengembangan pragmatis yang diperlukan untuk pembentukan. Penelitian tersebut menggunakan kerangka teori Relevansi Sperber dan Wilson. Selain itu (Wehberg et al., 2007) dalam penelitiannya "Danish children's first words: Analysing longitudinal data based on monthly CDI parental reports" suatu kajian pemerolehan bahasa pertama yang dilakukan pada anak di Denmark yang dilakukan secara longitudinal tiap bulan (8-30 bulan). Penelitian berfokus pada produksi, untuk mempelajari perkembangan leksikal awal dari kata pertama anak yaitu sekitar 100 kata yang diproduksi, lalu membagi periode ke dalam tahapan kata pertama: -1, -10, -25, -50, 50 dan -100. Kemudian tahap menganalisis kata-kata pertama dari anak-anak Denmark dihubungkan dengan konten semantik-pragmatis, struktur suara, dan komposisi leksikon awal berdasarkan pada kategori bahasa formal. Tahap terakhir yaitu membandingkan hasil dari bahasa Denmark yang mengungkapkan baik keseluruhan keseluruhan kata pertama anak-anak Denmark maupun perbedaan mencolok untuk beberapa kata tunggal. Penelitian tersebut cukup menarik dengan menggunakan adaptasi Denmark dari inventaris pembangunan komunikatif (CDI). Studi kasus penguasaan bahasa pada anak-anak juga dipengaruhi oleh kontingen pengasuhan dan mitra percakapan, serta oleh konsekuensi lain dari aspek berbicara, menurut (Petursdottir \& Mellor, 2017) kontingensi penguatan berperan besar dalam pemerolehan bahasa anak. Beberapa dekade penelitian yang berkelanjutan telah mendokumentasikan bagaimana mengatur kontingensi penguatan untuk mendukung penguasaan keterampilan bahasa dan komunikasi pada anak-anak dengan berbagai tingkat gangguan bahasa. Keahlian yang ada di bidang ini harus dimanfaatkan dalam desain model pemberian layanan yang memberikan peluang untuk kontinjensi penguatan yang efektif untuk beroperasi sepanjang hari dan mendukung perolehan keterampilan yang gagal berkembang melalui interaksi yang terjadi secara alami, sedangkan (Baptista, Gelman, \& Beck, 2014) menyatakan untuk menguji secara eksperimental penguasaan bahasa dengan penerapan pengamatan objek, lalu dengan eksperimental pertama untuk mengklarifikasikan gagasan kesamaan dengan memvariasikan tingkat dan jenis kesamaan yang diekspresikan dari penutur. (Veneziano, 2010) dalam "Conversation in language development and use: An Introduction" mengembangkan keterampilan percakapan pada anak-anak dan hubungannya dengan pemerolehan bahasa. Sentralitas percakapan dengan pengembangan bahasa diakui dengan baik untuk mengidentifikasi dua pendekatan kunci penelitian yaitu dampak dari proses percakapan pada penguasaan bahasa itu sendiri, dan bagaimana cara-cara dasar dalam keterampilan berbahasa yang digunakan untuk interaksi dalam suatu percakapan.

Berdasarkan beberapa penelitian di atas menunjukkan bahwa kajian pemerolehan bahasa pada anak sudah banyak dilakukan dan memiliki kajian yang cukup luas. Adapun beberapa persamaan yang menarik untuk diselidiki sehingga dapat bermanfaat dalam perkembangan ilmu pengetahuan. Persamaannya adalah meneliti tentang pemerolehan bahasa pertama pada anak, sedangkan perbedaannya adalah dari obyek penelitian yang meneliti bahasa dari beragam anak manca negara serta pengaruhnya, sedangkan penulis menggunakan obyek anak bahasa Indonesia yang difokuskan pada tahapan proses pemerolehan bahasa pertama secara linguistik yang ditekankan pada aspek fonologis yaitu suara dan pengucapan (sounds and pronunciation) dalam perspektif pragmatik yaitu kemampuan bunyi yang dihasilkan anak-anak dengan 
aturan pragmatis sesuai dengan usianya. Dengan demikian, pertanyaan dapat dikemukakan sebagai berikut: Bagaimanakah tahapan suara dan pengucapan dalam pemerolehan pragmatik pada anak usia 2 sampai 4 tahun?

\section{Metode}

Jenis penelitian adalah kualitatif dengan menggunakan pendekatan cross sectional yaitu dengan pengambilan data dari usia anak dua sampai empat tahun dalam waktu yang bersamaan agar memperoleh data yang lengkap dan cepat sehingga dapat menggambarkan tiap-tiap individu dalam proses pemerolehan bahasanya. Sampel penelitian adalah lima anak yang berusia dua sampai empat tahun yang menggunakan bahasa Indonesia. Fokus penelitian adalah segala bunyi atau suara yang diucapkan atau dihasilkan oleh anak dalam pandangan pragmatis yaitu ketika sedang berkomunikasi. Sub fokus dalam penelitian adalah suara dan pengucapan anak menurut teori (Susan M. Gass dan Larry Se, 2008). Proses pengumpulan data menggunakan catatan harian, alat rekam, dan wawancara yang dilakukan ke orang tua anak. Proses analisis data secara menyeluruh dalam rangka menemukan sebuah konsep melalui fenomena yang diamati dan dapat digunakan untuk menjelaskan fenomena, tema, dan pola studi kasus. Proses analisis data juga menganalisis pola dalam bentuk teks atau kejadian yang terjadi. (Kelly, Forshaw, Nordlinger, \& Wigglesworth, 2015) dalam metode penelitiannya menjelaskan bahwa pemerolehan bahasa pertama pada anak perlu memperhitungkan data dari beragam tipologi bahasa dan lingkungan pembelajaran bahasa untuk mengidentifikasi potensi universal dalam pengembangan bahasa anak-anak, bagaimana cara berinteraksi dengan mekanisme pemerolehan sosial-budaya. Literatur berbasis lapangan juga menunjukkan keragaman dalam jumlah peserta dan pengelompokan usia yang akan dipelajari, serta lamanya waktu yang dipelajari oleh anak-anak.

\section{Hasil dan Diskusi}

Awal dimulainya belajar bahasa pada seorang anak adalah dengan menentukan tentang bahasa apa saja yang didengar oleh anak. Dalam proses penguasaan tata bahasa seperti: fonologi, morfologi, sintaksis, semantik, dan pragmatik secara tidak disadari dibawa oleh tiap-tiap anak sejak lahir. Adapun tahapan proses pemerolehan bahasa pertama pada anak adalah: Babbling (mengoceh), tahapan yang terjadi pada usia sekitar enam bulan, yaitu bayi beralih ke suara yang lebih mirip bahasa yang disebut 'babbling atau mengoceh'. Dalam proses mengoceh paling sering terjadi yaitu terdiri dari urutan konsonan-vokal seperti: 'bababa, dadada, kemudian bada'. Words (kata-kata), yaitu tahapan munculnya awal kata yang dapat dikatakan memiliki fungsi sebagai suatu pemenuhan kebutuhan pada anak. Misalnya, ketika anak merujuk ke suatu objek, seperti kata 'ba' untuk 'botol' maka dapat dikatakan anak-anak dapat menunjukkan berbagai fungsi dari tata bahasa, mencatat satu anak (usia 19-20 bulan) yaitu anak-anak sering melebihlebihkan arti kata-kata yang mereka tahu. Misalnya, menggunakan kata 'kelinci' untuk merujuk pada boneka, gambar orang, beruang, kursi, lampu, puzzle, kereta api, dan sebagainya. Sounds and Pronunciation (suara dan pengucapan), pada tahapan awal pengucapan anak tidak sama dengan pengucapan orang dewasa. Syntax (sintaksis), setelah melalui tahapan satu kata, anak-anak mulai menggabungkan beberapa kata biasanya terjadi sekitar usia dua tahun. Ciri khas dari fase ini adalah katakata yang digunakan konten antara kata benda dan kata kerja. Fungsi kata seperti preposisi dan akhiran gramatikal sangat kurang, namun ucapan yang digunakan mirip dengan ucapan yang biasa digunakan saat mengirim pesan. Misalnya, ucapan yang dilakukan oleh anak-anak: Aaron go home, Seth play toy, atau Ethan no go. Morfologi, Brown dalam (Ingram, 1989)mengungkapkan bahwa kemunculan morfem gramatikal konsisten pada anak-anak dan berhubungan dengan perkembangan anak secara keseluruhan. Pada pemerolehan morfologis yakni pada periode kalimat dua kata, seorang anak sudah mulai membuat kalimat dan dalam proses merangkai kalimat, perubahan-perubahan terjadi pada pilihan kata yang menggunakan inmbuhan dan kemudian diikuti diferensiasi morfologi, yaitu ketika seorang anak mulai menggunakan kelas kata yang makin bervariasi. Berikut ini merupakan data melalui hasil pengamatan dan pencatatan beberapa anak usia dua sampai empat tahun: 


\begin{tabular}{|c|c|c|c|c|}
\hline $\begin{array}{l}\text { AFA } \\
(2,8)\end{array}$ & $\begin{array}{l}\text { RSP } \\
(2,7)\end{array}$ & $\begin{array}{l}\text { SAF } \\
(2,5)\end{array}$ & $\begin{array}{c}\text { MR } \\
(3,5)\end{array}$ & $\begin{array}{l}\text { ASA } \\
(4,4)\end{array}$ \\
\hline Data I: & Data I: & Data I: & Data I: & Data I: \\
\hline $\mathrm{P}$ : main apa kak & $\mathrm{P}$ : minta dunk ki & A: mas..jatoh & P: Reyhan mama & P: ka Syifa besok \\
\hline Lula? & banyak amat & (melihat anak & mana? & pulkam g? \\
\hline A: nih.. (Dengan & uangnya! & laki-laki di tv & A: kerja & A: iya pulang \\
\hline menunjukkan satu & A: tidak boleeh & sedang naik di & P: masuk malam & P: diantar papa apa \\
\hline alat permainan) & P: mau beli apa & pohon) & yaa & pulang ama mama aja? \\
\hline $\mathrm{P}$ : yang dipegang & A: Aku mau beli di & Ibu: iyaa..gak & A: iyaa papa & A: diantar papa, nanti \\
\hline $\begin{array}{l}\text { Lula : } \\
\text { Lat }\end{array}$ & yang dibeli, ada & $\begin{array}{l}\text { bolen na1k-naik } \\
\text { gitu ya..nanti }\end{array}$ & $\begin{array}{l}\text { piket, nant } \\
\text { tidur ama }\end{array}$ & $\begin{array}{l}\text { dijemput lagi ke rumah } \\
\text { dijes }\end{array}$ \\
\hline em..beek..(hewan & maenan ada & jatuh & mbanya. & Uti.. \\
\hline Kambing) & minuman (bicara & A: buk..atoh.. & P: pulangnya jam & P: lama di rumah eyang \\
\hline $\mathrm{P}$ : boleh pinjam & terus kadang tidak & ibu: iya jatuh & berapa Reyhan? & uti? \\
\hline mainannya g? & jelas) & $\mathrm{P}$ : fahrul berani $\mathrm{g}$ & A: mama besok, & A: iya sampe libur \\
\hline A : ni..ni..nan & P: udah sekolah & naik gitu : & papa pagi nanti & sekolah \\
\hline kaka.. & belum? & A: (diam..) & langsung tidur. & $\mathrm{P}$ : masuk tanggal \\
\hline $\mathrm{P}$ : iya ini semua & A: belom laah, kaka & P: eh adiknya & P: Reyhan berani & berapa ka? \\
\hline mainan ka lula, & aku yang udah & tante minta yaa & di rumah? & A: lupa mama arsya \\
\hline boleh pinjam? & sekolah, pulangnya & P:ndak(tidak) & A: berani, kan ada & mama yang tahu, \\
\hline A: (tidak menjawab & sore dia naik ojol. & $\mathrm{P}$ : nama adiknya & mbak (ART). & soalnya udah dikasih \\
\hline dan asyik dengan & Data II: & & Data II: & tahu ama bu guru \\
\hline mainnannya). & P: Assalamuallaikum & A: (diam) & A: tante mas arsya & P: oh gitu.. \\
\hline Data II : & A:kumsalam..ibuu & Ibu: namanya & udah pulang & Data II: \\
\hline P: nonton apa ka? & ada mama mas arsya. & siapa..Azale.. & sekolah & P:Assalamuallaikum \\
\hline A: (diam) & P: Ki..makan apa? & A: ya (Azalea') & P: belum & A: Waallaikumsalam \\
\hline P: hewan apa itu & A: (tidak menjawab & P: siapa nama & Reyhan..nanti & P: ka mama ada \\
\hline $\mathrm{ka} ?$ & dan makan sambil & adiknya? & siang yaa & A: keluar sama papa \\
\hline A : pih..(sapi) & nonton tv) & A: ya..la.. fa & A: mau pinjam & P: ka Syifa sendiri \\
\hline P: kalau yang itu? & P: telor melulu, $\mathrm{g}$ & (Azalea Fayola & hewan mas arsya & A: atheu lagi tidur \\
\hline A:japah (Jerapah) & bosen apa? & Nadhifa) & (mainan binatang) & (sebutan tante) \\
\hline P: ini apa? & A:enggak lah telor & P:kalau nama & P: boleh..mau & A: WA mama aja \\
\hline A: gajah & itu enak, aku suka & lengkap Fahrul? & yang mana coba & P: lagi g bawa hp \\
\hline P: ini ? & aku makan pake & Hapal g? & sebutin dulu! & A: mau aku WA in \\
\hline A: babi & kecap (bicara telur & A: (tidak & A: dinosaurus, & P: g usah, \\
\hline P: kalau ini ka & lalu ke topik lain) & menjawab dan & jerapah, sapi, & P: ka suka boneka \\
\hline A: uda (Kuda) & $\mathrm{P}$ : maen ke mas & melihat ibunya) & (cukup banyak & hewan,banyak amat \\
\hline P: ini ? & Arsya yuk! & Ibu: Syaif Arkhan & dan jelas) & bonekanya? \\
\hline A: Singa & A: enggak mau..NO.. & Fahrudin & A: Reyhan boleh & A: paling suka sapi \\
\hline P: pintar ni kaka.. & A: eh..eh.. itu ada & A: din.. & mainan sini yaa.. & ama pig aja (pig 'babi') \\
\hline & Douglas, kevin, & (melanjutkan & P: yaа.. & P: yang belikan siapa \\
\hline & victor, Timothy, & nama belakang & A: Pintunya & $\mathrm{ka}$ ? \\
\hline & $\begin{array}{l}\text { edward..(acara } \\
\text { televisi Thomas and } \\
\text { Friends) }\end{array}$ & saja) & jangan ditutup ya & $\begin{array}{l}\text { A: papa, yang dongkey } \\
\text { dikasih atheu. }\end{array}$ \\
\hline
\end{tabular}

Pembahasan pertama adalah anak yang bernama Alula Farzana Ayunindya (AFA), lahir pada tanggal 10 Desember 2016. Latar belakang orang tuanya sama-sama menggunakan bahasa Jawa dalam komunikasi sehari-hari, namun untuk berkomunikasi dengan anak menggunakan bahasa Indonesia. Sebagai anak pertama dalam bertutur atau berkomunikasi Lula yang berusia 2 tahun 8 bulan menjawab beberapa pertanyaan dengan ucapan kata yang sangat pendek dan sederhana, untuk meminta sesuatu lebih sering menunjuk benda yang diinginkan lalu diikuti dengan satu atau dua kata yang banyak diakhiri pada kata belakangnya. Proses penghapusan suara yaitu dapat dilihat pada kata yang menunjuk beberapa hewan seperti: 'pih $\rightarrow$ sapi,' 'uda $\rightarrow k u d a$ ', 'japah $\rightarrow$ jerapah'. Pada tahap permulaan pemerolehan bahasa pada anak biasanya anak memproduksi perkataan orang dewasa yang disederhanakan agar lebih mudah untuk diucapkan namun secara makna Lula sudah memahami seperti hewan yang dimaksudkan pada penghapusan suku kata 'em...bek' $\rightarrow$ 'kambing'. 
Kedua, Rizki Sidata Putra (RSP) lahir pada tanggal 25 Januari 2017. Ia merupakan anak ketiga, dua kakaknya sudah memasuki usia sekolah yaitu jenjang sekolah menengah pertama kelas VIII dan sekolah dasar kelas VI. Sebagai anak laki-laki dengan usia yang sama dengan Lula, Rizki termasuk anak yang banyak bicara dan lancar dalam pengucapan. Dari hasil wawancara dengan orang tuanya, dapat diketahui bahwa Rizki memiliki kemampuan berbahasa yang baik. Kalimat-kalimat yang disampaikannya sudah dapat dimengerti oleh orang lain. Dalam percakapan pun ia sudah dapat menggunakan kata-kata yang menghubungkan sebab akibat. Selain itu, Rizki juga sangat pintar dan kritis dalam berbicara, ia sering menggunakan bahasa Indonesia dan bahasa Inggris melalui tontonan televisi. Dari beberapa jawaban yang dituturkan sangat jelas bahwa dia sangat lancar dan mudah mencerna apa yang ditanyakan oleh peneliti terhadapnya, bahkan hal-hal yang tidak ditanyakan pun dia menceritakannya seperti bercerita yang cukup panjang. Dalam berbicara anak Rizki juga sering menggunakan bahasa Indonesia baku dalam percakapannya. Jumlah ujaran-ujaran yang diucapkan relatif panjang dan sangat mudah untuk dimengerti. Dia mampu menceritakan suatu hal kepada orang dewasa dengan sangat lancar, dalam proses suara dan pengucapan ditemukan penghapusan suara pada kata 'kumsalam' yaitu mengacu pada jawaban sapaan 'waallaikumsalam'. Hanya saja, ada beberapa tuturannya yang tidak terstruktur dengan baik, misalnya "belom laah, kaka aku yang udah sekolah, pulangnya sore dia naik ojol" dan "enggak lah telor itu enak, aku suka aku makan pake kecap (bicara telur lalu ke topik lain)".

Ketiga, Syaif Arkhan Fahrudin (SAF) lahir pada tanggal 18 Februari 2017, ia merupakan anak pertama dengan latar belakang orang tua yang berbahasa Jawa. Dalam berkomunikasi sehari-hari menggunakan bahasa Indonesia juga bahasa Jawa. Dalam bertutur Fahrul lebih banyak diam dan dalam mengucapkan kata-kata lebih banyak kata-kata yang terpenggal. Dalam kasus tersebut terlihat bahwa pada anak usia 2 tahun 5 bulan sebenarnya sudah dapat berkomunikasi dengan baik walaupun belum lancar. Komunikasi secara terbatas dialami oleh Fahrul jika ditanya oleh orang lain yaitu tidak langsung akan menjawab, biasanya diam lalu memanggil ibunya. Pada percakapan yang dilakukan pada anak Fahrul terdapat penghapusan suara pada kata 'buk $\rightarrow$ ibu', 'toh $\rightarrow$ jatuh', ' ya $\rightarrow$ Azalea', 'la $\rightarrow$ Fayola', 'fa $\rightarrow$ Nadhifa', 'din $\rightarrow$ untuk penyebutan nama lengkap Syaif Arkhan Fahrudin'. Dengan demikian, anak Fahrul cenderung masih egosentris dan belum begitu jelas dalam berbicara. Pengucapan masih sangat sederhana, artinya dapat dikatakan Fahrul baru dapat memproduksi satu sampai dua kata untuk mengungkapkan apa yang diinginkannya.

Keempat, Muhammad Reyhan (MR) lahir pada tanggal 22 Januari 2016, ia merupakan anak pertama dari dua bersaudara. Penguasaan bahasa yang dikuasai Reyhan yang berusia dapat dikatakan cukup baik, berdasarkan hasil pengamatan proses pengucapan dalam giliran bertutur menjawab pertanyaan dari lawan tutur dengan lancar dan kalimat yang relatif lengkap. Dari hasil wawancara dengan orang tuanya Reyhan kecil sudah aktif diajak berbicara dan sering dibawa ke sekolah tempat utinya bekerja sehingga dia memiliki kemampuan bertutur yang lebih baik jika dibandingkan dengan anak pada usia tiga tahun yang umumnya sudah mampu menyusun kalimat dalam bertutur namun masih sangat sederhana dan terbatas. Pada anak MR penulis menemukan proses pengucapan pada anak yang menggunakan kata-kata yang kurang lebih menyerupai kata-kata orang dewasa, sehingga tidak ada perbedaan baik arti juga dalam pengucapannya.

Kelima, yaitu Ananda Syifa Aquina (ASA) lahir pada tanggal 2 Fabruari 2015, pada usia empat pemerolehan bahasa Syifa pada tataran pengucapan yang cukup baik. Hal ini terlihat dari data yang didapatkan. Pada usia ini ia sudah mulai berbicara dengan kalimat-kalimat yang sederhana kemudian menjadi kalimat yang kompleks. Selain itu, dalam melakukan percakapan Syifa juga sudah mengerti makna dari tiap-tiap ujarannya maupun lawan tuturnya. Baik ujaran maupun pengucapan relatif panjang dan sangat mudah untuk dimengerti. Dia mampu menceritakan suatu hal kepada orang dewasa dengan sangat lancar. Hal ini dapat juga disebabkan ole faktor lingkungan yaitu sekolah karena di usianya 2, 5 tahun oleh orang tuanya sudah dimasukan ke bimbingan belajar dan masuk sekolah pendidikan anak usia dini. Jadi, pemerolean bahasa pertama yang dikuasai juga diperkuat oleh lingkungan pendidikan.

\section{Simpulan}

Bahasa berkembang dalam diri anak secara spontan, tanpa usaha sadar atau instruksi formal yang digunakan untuk memahami logika yang mendasarinya. Dalam memperoleh suatu bahasa, anak-anak mempelajarinya melalui proses pemerolehan bahasa yang sebenarnya telah diperoleh sejak lahir, hal 
tersebut berlangsung secara alami, artinya tidak dengan cara menghapalkan kosakata atau aturan-aturan secara gramatikal. Adapun tahapan proses pemerolehan bahasa pertama pada anak adalah, babbling, words, sounds and pronunciation, syntax, morfologi, semantik, dan pragmatik. Pada tahapan awal pengucapan anak satu dengan yang lainnya tidak sama pengucapannya dengan orang dewasa. Beberapa suara dapat dibedakan di awal saja seperti: perbedaan antara konsonan atau adanya perbedaan pengucapan baik dalam penghapusan suku kata, penghapusan suara, dan proses penyerdehanaan seperti kata. Perbedaan tersebut terlihat dari usia, pada tahapan usia anak maka akan berpengaruh pada perbedaan antara bunyi konsonan atau adanya perbedaan pengucapan.

\section{Ucapan Terima Kasih}

Alhamdulillah ucapan puji syukur karena penelitian ini dapat terselesaikan tepat pada waktunya. Penulis menyadari perlunya berdoa serta kerja keras untuk menyelesaikan artikel ini, selain usaha tersebut juga memperoleh bantuan dari semua pihak, untuk itu penulis ingin ucapkan terima kasih kepada yang terhormat yaitu Prof. Dr. Zainal Rafli, M.Pd. dan Dr. Ninuk Lustyantie yang selalu memberikan bimbingan, arahan dengan ikhlas, dan penuh kesabaran sehingga penelitian tentang kajian Pemerolehan dan Pembelajaran Bahasa Kedua dapat terselesaikan

\section{Daftar Rujukan}

Baptista, Marlyse, Susan A. Gelman, and Erica Beck. "Testing the role of convergence in language acquisition, with implications for creole genesis." International Journal of Bilingualism 20.3 (2016): 269-296. https://doi.org/10.1177/1367006914552459

Ingram, David. First language acquisition: Method, description and explanation. Cambridge university press, 1989.

Kelly, Barbara F., et al. "Linguistic diversity in first language acquisition research: Moving beyond the challenges." First Language 35.4-5 (2015): 286-304. https://doi.org/10.1177/0142723715602350

Kidd, Evan, Seamus Donnelly, and Morten H. Christiansen. "Individual differences in language acquisition and processing." Trends in cognitive sciences $22.2 \quad$ (2018): 154-169. https://doi.org/10.1016/j.tics.2017.11.006

Petursdottir, Anna Ingeborg, and James R. Mellor. "Reinforcement contingencies in language acquisition: Implications for language intervention." Policy Insights from the Behavioral and Brain Sciences 4.1 (2017): 25-32. https://doi.org/10.1177/2372732216686083

Liszka, Sarah A. "Exploring the effects of first language influence on second language pragmatic processes from a syntactic deficit perspective." Second Language Research 20.3 (2004): 212-231. Retrieved from University ofLondon, The British Institute in Paris

Susan M. Gass and Larry Se. "Second Language Acquisition: An Introductory Course (review)." In Language (Third edit, Vol. 79), 2008. https://doi.org/10.1353/lan.2003.0126

Thornton, Rosalind. "Studies at the interface of child language and models of language acquisition." First Language 32.1-2 (2012): 281-297. https://doi.org/10.1177/0142723711403881

Veneziano, Edy. "Conversation in language development and use: An introduction." (2010): 241-249. https://doi.org/10.1177/0142723710380531

Wehberg, Sonja, et al. "Danish children's first words: Analysing longitudinal data based on monthly CDI parental reports." First Language $27.4 \quad$ (2007): 361-383. https://doi.org/10.1177/0142723707081723 